\begin{tabular}{lcccr} 
T H E & A R C H I V E & O F & M E C H A N I C A L & E N G I N E E R I N G \\
\hline VOL. LVII & 2010 & Number 3
\end{tabular}

10.2478/v10180-010-0015-x

Key words: bolt joint, special finite elements, stiffness characteristics

\title{
ANALYSIS OF BOLT JOINT USING THE FINITE ELEMENT METHOD
}

\begin{abstract}
A numerical analysis of the initially clamped bolt joint subject to the working pressure is presented in the paper. Special, hexahedral 21- and 28-node isoparametric finite elements have been employed to model the contact zone. In this model, one takes into account loading due to the working pressure in the gap between the gasket and the flange arising as an effect of the progressing joint opening, what has not been considered in recent papers. Nonlinear stiffness characteristics of the bolt and the flange with the gasket are developed. Working pressure corresponding to the critical bolt force resulting in the joint leakage (complete opening between the gasket and the flange) is determined. FE computational results are compared with the available experimental results. The numerical results are presented using the authors' own graphical postprocessor.
\end{abstract}

\section{Subject of analysis}

Flange joints are commonly used, e.g. in pipeline connections. Various aspects concerning approximate analytical calculations in a one-dimensional form, properties and servicing of the bolt joints are described in [1,2,3]. Osgood [4], Motosh [5], Shigly and Mischke [6] discussed in their works the flange connections in which the contact surfaces, which include the area between the flanges and the gasket, are assumed to be constant and without friction between the flange and the gasket. The nonlinear force-deflection behaviour of the connection was presented in Junker [7] and Bickford [8]. In the papers by Zahavi and others $[9,10,11]$, one can find numerical analyses based on the finite element method that make use of commercial finite ele-

* Maritime University of Szczecin, Division of Computer Methods, H. Poboznego 11, 70-507 Szczecin, Poland; E-mail: bartek.zylinski@StrataMarineOffshore.no (B.Ż) and r.buczkowski@am.szczecin.pl (R.B) 
ment packages ANSYS and NASTRAN [9,10,11], which take into account the nonlinear stiffness characteristics of the bolt joints.

The flange joints belong to the group of initially-clamped joints where the bolts are pre-stressed before applying working loading. The initial clamp is important for the joint behaviour, especially in pressure vessels and pipelines.

The joint presented in Fig. 1 was analysed numerically. The geometry, material properties, the value of the initial force of $15 \mathrm{kN}$ and dimensions of the example were taken from Sawa, Higurashi and Akagawa [12]. It was also considered in ABAQUS Example Problems Manual where the sticking contact conditions were assumed in all contact areas. Here, this solution is physically more realistic, since gaskets separate from their neighbouring parts when subjected to tensile loading.

Selection of finite elements and control of the contact condition by the nodal contact forces must result in positive equivalent nodal forces. Adopting the standard 20-node (C3D20 or C3D20R according to nomenclature taken from ABAQUS) or 32-node hexahedral elements results in equivalent nodal forces of both compressive and tensile type. The corner nodal forces become negative and the midside ones are positive. Thus, the elements do not represent the contact phenomenon properly. Because the standard second-order brick elements of the Serendipity family can not be used in modelling of the contact zone, special 21- or 28-node hexahedral elements were employed in the present analysis $[13,14]$.
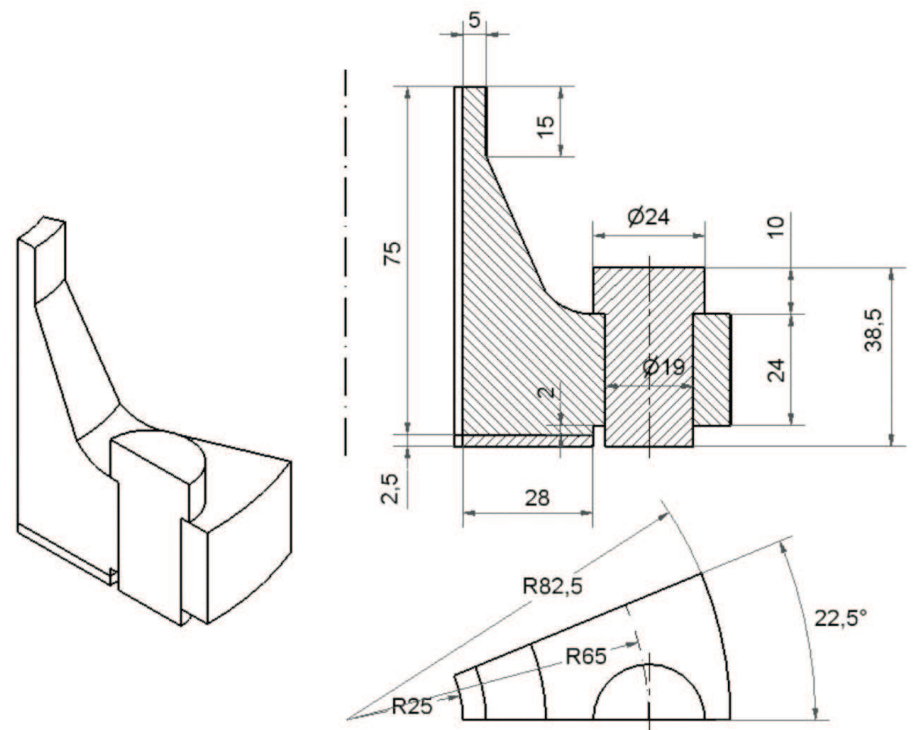

Fig. 1. Bolt joint (22.5 degrees sector) 
The dimensions and shape of the joint comply with the following standards: JIS B (Japanese standard) and ANSI B 16.5 (American standard). The joint was investigated experimentally at a real research stand [12].

Due to the cyclic symmetry of the joint, a sector of 22.5 degrees was analysed numerically.

In the basic variant, the joint is composed of (Fig.1):

- two flanges having internal diameter of $50 \mathrm{~mm}$ and external diameter of $165 \mathrm{~mm}$ each,

- gasket of internal diameter of $50 \mathrm{~mm}$ and external diameter of 108 $\mathrm{mm}$ and thickness of $3 \mathrm{~mm}$ or $5 \mathrm{~mm}$,

-8 bolts located at the pitch diameter of $130 \mathrm{~mm}$.

The flanges used in the experiment were made of steel (for structural use, S45, acc. to JIS).

Bolts with thread M16 were made of chrome-molybdenum steel. The bolt shaft diameter (length of $20 \mathrm{~mm}$ ) was reduced to $14 \mathrm{~mm}$ to locate strain gauge. In the basic variant, an aluminium gasket was applied (Al.-H, according to JIS). The material constants were:

- for the flange: $E=206000 \mathrm{MPa}, v=0.3$,

- for the bolts: $E=206000 \mathrm{MPa}, v=0.3$,

- for the gasket: $E=68700 \mathrm{MPa}, v=0.3$.

After the flanges were assembled together with the gasket, each of the bolts was pre-tensioned with the force of $F=15 \mathrm{kN}$.

\section{Computational model}

\subsection{Finite element model}

According to the above-described assumptions (cyclic symmetry), we developed a model corresponding to the sector of 22.5 degrees of the bolt joint. The model presented in Fig. 2 is composed of:

- the flange (red colour - 342520 -node finite elements beyond the contact zone, and 21-node (denotation: C3D21 [13]) or 28-node (denotation: C3D28 [14]) solid finite elements in the contact zone),

- the gaskets (white colour - 192 21- or 28-node solid finite elements),

- the bolts (green colour - 62620 - or 21-node solid finite elements, Fig. 3).

In the contact zone, between the gasket and the flange, there are 128 elements (C3D21 type) or, in another computational variant, 128 elements (C3D28 type). 64 solid elements modelling the gasket and 64 elements belonging to the flange are shown in Fig. 4. 


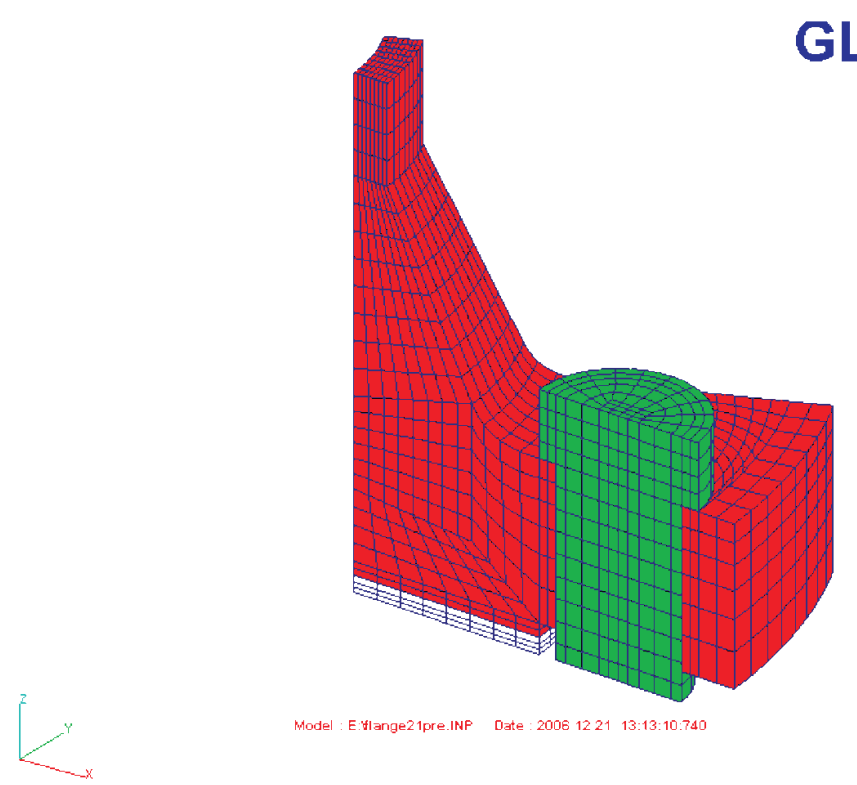

GLON

Fig. 2. FE model of bolt joint

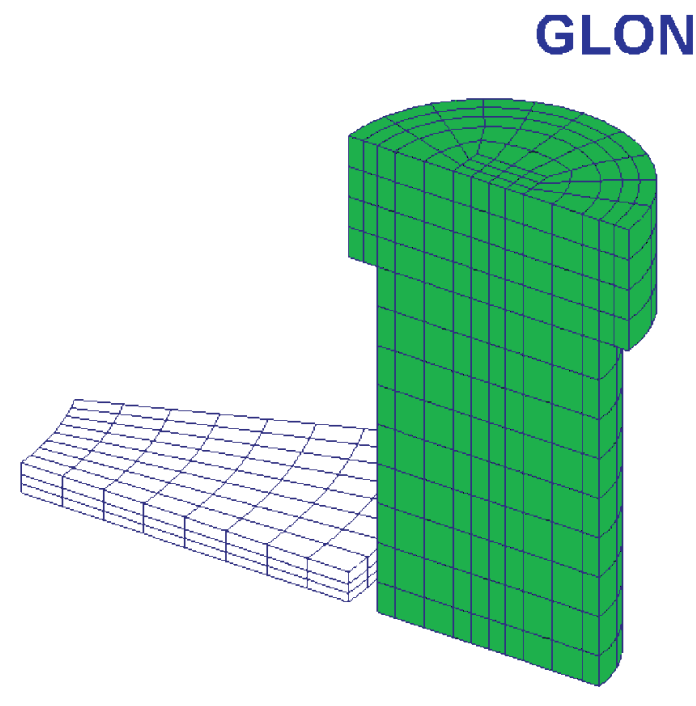

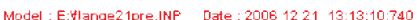

Fig. 3. Finite element mesh of bolt and gasket 


\section{GLON}

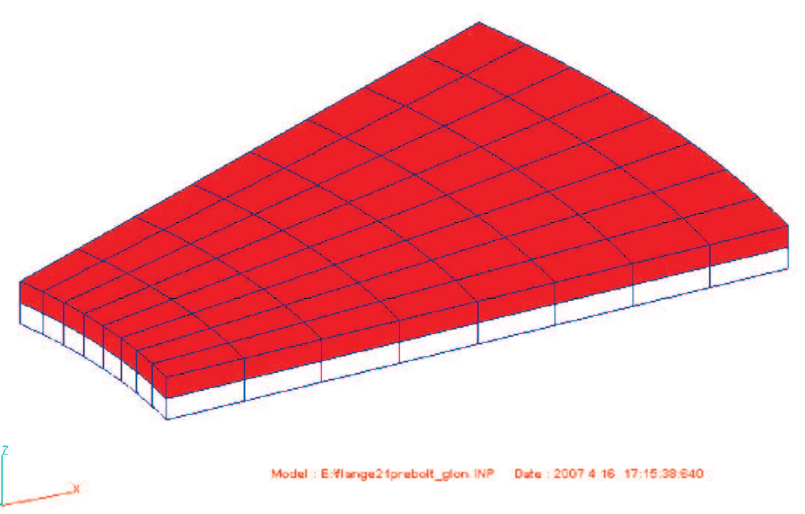

Fig. 4. Elements in contact zone (flange gasket); the left and right gasket edges correspond to internal diameter of $50 \mathrm{~mm}$ and external diameter of $108 \mathrm{~mm}$, respectively

In the zone contact, between the bolt head and the flange, 40 elements (C3D21 type) were applied; twenty of them modelled the bolt head and another twenty - the flange.

\subsection{Boundary conditions and joint loading}

On the surfaces of cyclic symmetry, displacements were fixed in the direction normal to these surfaces. Displacements in the vertical direction ( $z$ axis) were fixed for the nodes located at the bottom surface of the gasket and bolt.

The joint was loaded as follows:

(i) initial clamp realised through compressive loading applied to the bolt $F=15 \mathrm{kN}$,

(ii) pressure corresponding to the working pressure $p$ applied to the element faces forming the internal surface of the flange and gasket.

At the top surface of the flange neck of the area

$$
A=\pi\left(30^{2}-25^{2}\right)=275 \pi
$$

the applied tensile loading was equal to:

$$
P_{k}=\frac{\pi \cdot 25^{2} p}{\pi\left(30^{2}-25^{2}\right)}=2.2727 p
$$


As the separation of the flange and the gasket was progressing, the working pressure was also applied to the faces of C3D21 (or C3D28) elements, forming the contact surfaces of the flange bottom and gasket which moved outside the contact zone.

\subsection{Numerical analysis}

The objective of the numerical analysis was:

- to evaluate the maximum working loading that is the maximum pressure the system can sustain without leakage (total opening between the flange bottom and the gasket),

- to evaluate the maximum stresses in the flange,

- to develop stiffness characteristics,

- to compare the obtained results with the data from the experiment.

Numerical computations were divided into two phases:

- phase one: initial clamp caused by pre-tensioning in the bolt,

- phase two: loading by working pressure $p$ increasing in 2 MPa steps.

In the second phase, each time the working loading was applied, the joint opening was checked and the contact pressure on the gasket surface was determined.

In the basic variant of the analysis (computational results compared with the available experimental results [12]), the following data were taken:

- gasket thickness $-d=5 \mathrm{~mm}$,

- initial clamp of the bolt $-F=15000 \mathrm{~N}$ (phase one).

In the other study, the gasket thickness was taken $d=3 \mathrm{~mm}$ and the initial clamp force $F=7.5 \mathrm{kN}, F=10 \mathrm{kN} \mathrm{i} F=20 \mathrm{kN}$, respectively.

\subsubsection{Computational results (phase one - initial clamp)}

The distribution of contact pressures on the top gasket surface (C3D21 type elements) is presented in Fig. 5. The obtained results prove that, already for the initial clamp, the contact between the gasket and flange is lost (blue colour in Fig. 5).

Beyond the zone where the opening takes place, the values of the contact pressure increase together with the distance along the gasket radius. The greatest values appear in the nodes located in the external part of the gasket. Differences in the contact pressure values appear also along the radius on both gasket edges (Figs. 6 and 7). It can be presumed that the differences will increase as the working load is applied. It was assumed that leakage will take place first at the right gasket edge. The total opening can occur even when the gasket is in contact with the flange on the other side. The comparison of the contact pressure distribution along the gasket radius, computed with 


\section{GLON}
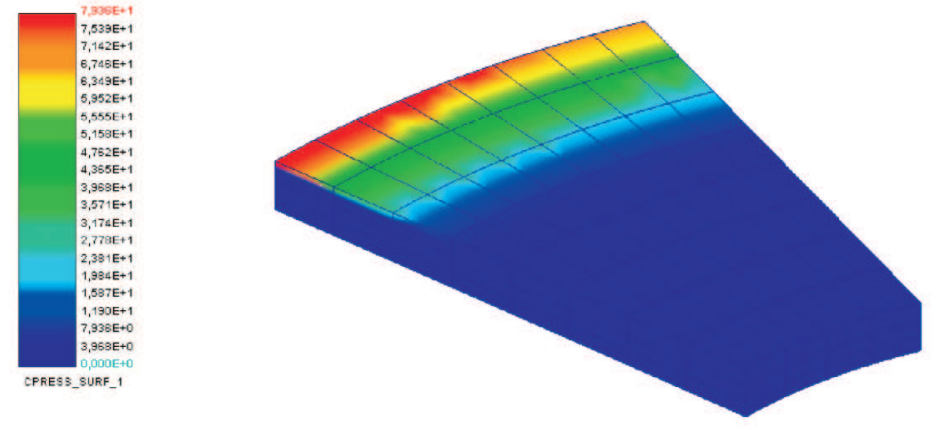

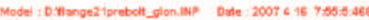

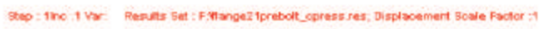

Fig. 5. Distribution of contact pressure $[\mathrm{MPa}]$ on gasket, initial clamp $F=15 \mathrm{kN}$

the use of C3D21 and C3D28 elements, respectively, is presented in Fig. 7 - the diagram refers to the right gasket edge.

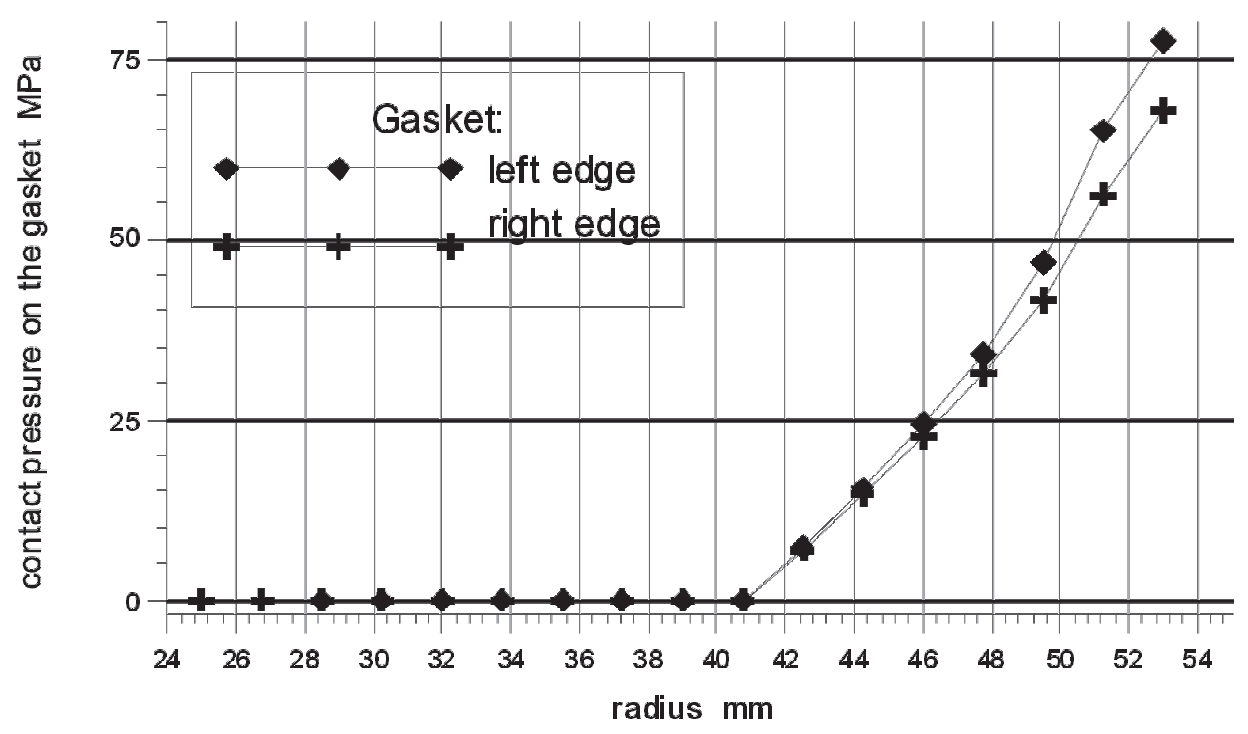

Fig. 6. Contact pressure distribution along gasket radius edge on both edges

\subsubsection{Computational results (phase two - working load)}

As the workig load was increased, one could observe separation of the flange from the gasket and the decrease in the contact pressure on the gasket. It could be seen that the contact pressure at one of the edges of the gasket was 


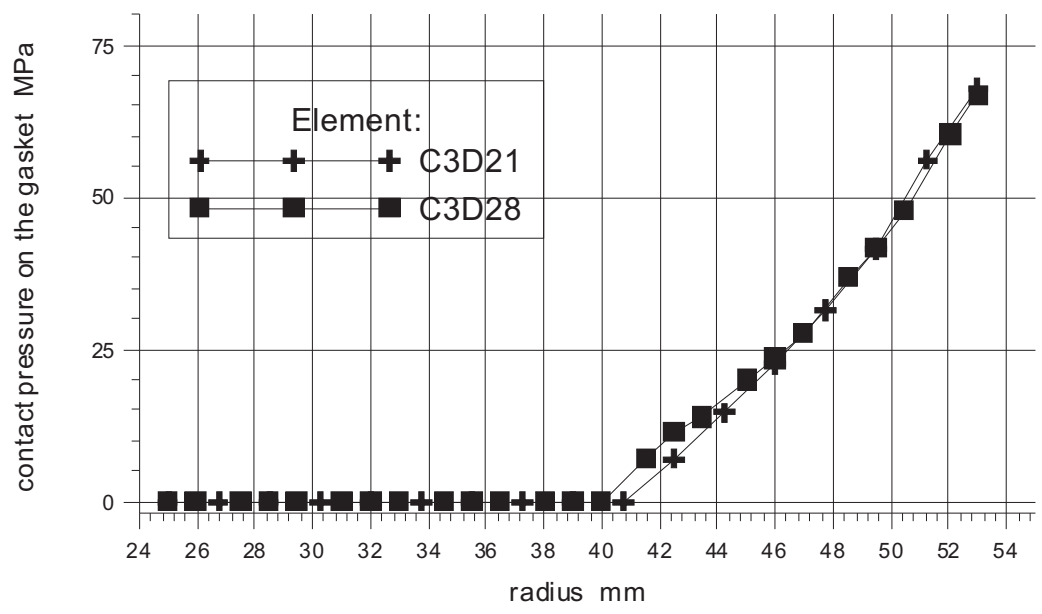

Fig. 7. Contact pressure distribution along gasket radius (the right gasket edge)

lower. When the working pressure was equal to $16 \mathrm{MPa}$, close to the place at the edge where the contact pressure was initially lower, an opening occurred along the whole length of the gasket. Despite the fact that the gasket was still in contact with the flange at the other side, the leakage was occured at $16 \mathrm{MPa}$. Distributions of the contact pressures, calculated for different values of the applied working pressure, are presented in Fig. 8. Pressure distribution on the gasket for the working pressure of $16 \mathrm{MPa}$ is shown in Fig. 9.

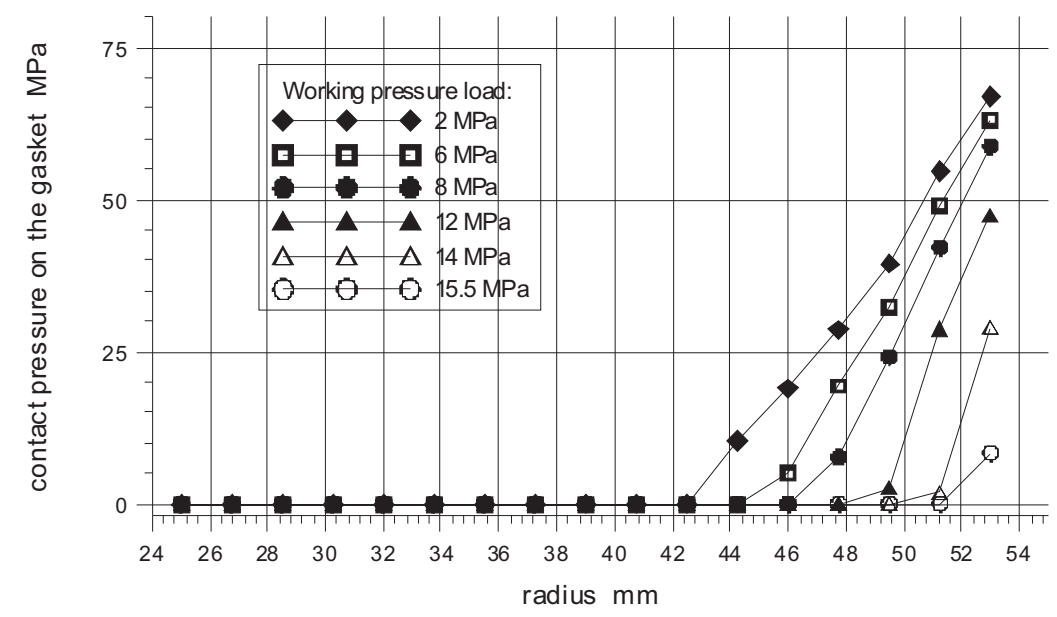

Fig. 8. Values of contact pressures between the flange and gasket depending on working load 


\section{GLON}
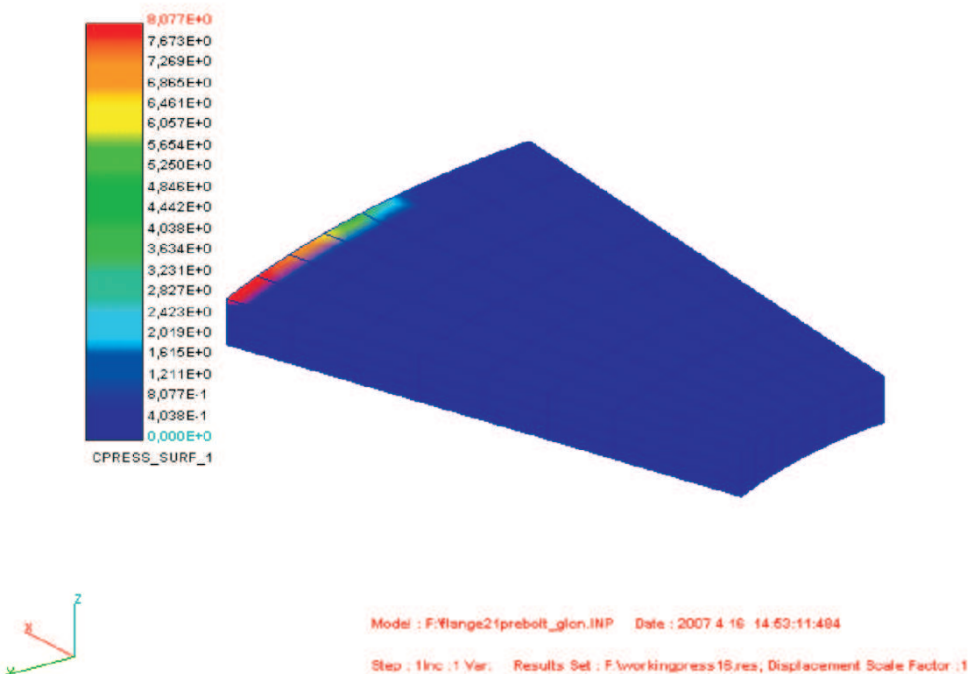

Fig. 9. Contact pressure distribution for working load of $16 \mathrm{MPa}$

\subsubsection{Comparison of computational results with experimental data}

The dependence between the bolt force and the applied working load is presented in Fig. 10.

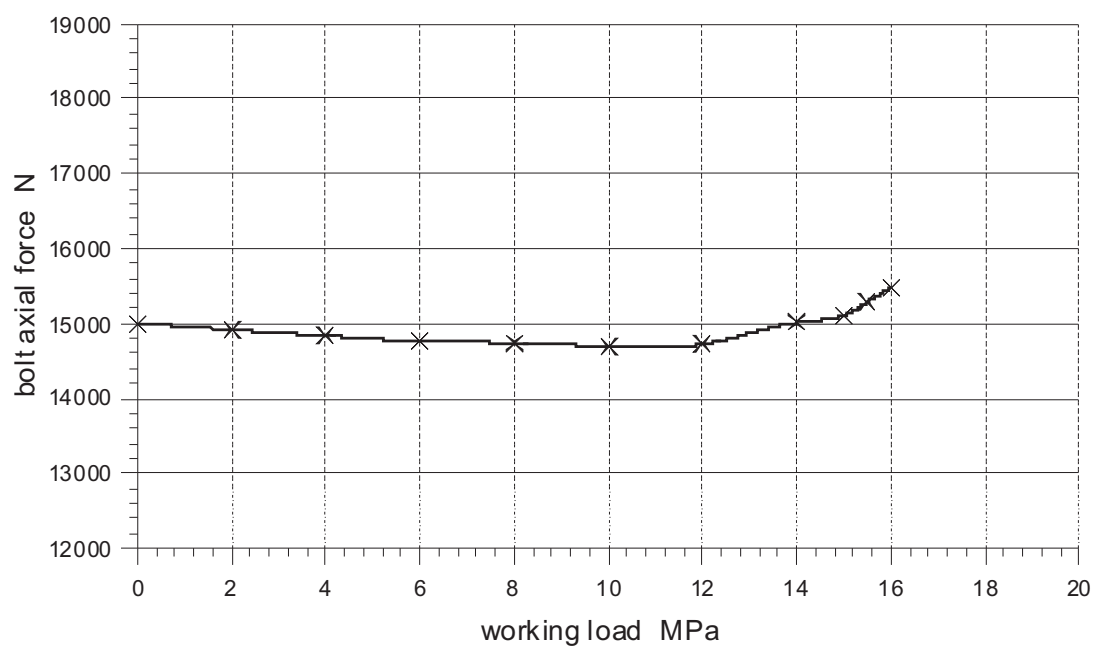

Fig. 10. Bolt force depending on working load 
In the result of the computations it was found that the leakage in the joint occurred for the value of the working pressure of $p=16 \mathrm{MPa}$. The obtained computational results were compared to the experimental results [12]. A good agreement between both results was found. The leakage in the experiment was detected at the working pressure $p=16.5 \mathrm{MPa}$ (Fig. 11).

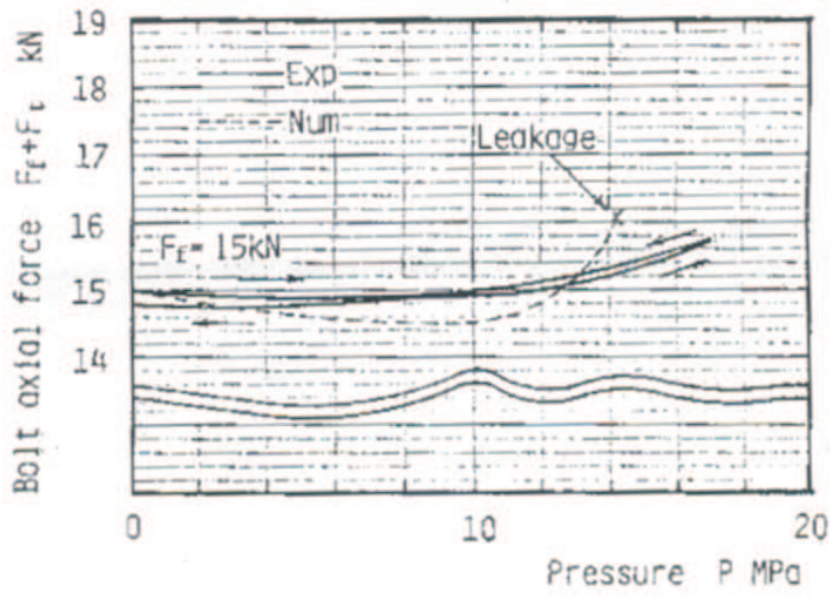

Fig. 11. Bolt force $\left(F_{f}+F_{t}\right) v s$. working pressure $p$ - experimental results [12]; $F_{f}=15 \mathrm{kN}$ denotes the initial force, $F_{t}$ is an increment in axial bolt force due to working pressure $p$

The deformed model of the joint for the working pressure of $16 \mathrm{MPa}$ is presented in Figs. 12 and 13.

In Fig. 12, owing to the applied rescaling (scale coefficient 100), one can see complete separation of the flange and the gasket (leakage). In Fig. 13, the deformed bolt is presented. It is clearly seen that bending of all elements of the joint takes place here.

Stresses in the flange were also measured in the experiment [12]. The place of tensometric measurements and the measured stresses in the function of the applied working load are presented in Fig. 14.

Distributions of von Mises stresses in the flange in the case of working load of $16 \mathrm{MPa}$ (deformed model, scale 100) are presented in Fig. 15. The greatest calculated stresses occur at the contact between the bolt head and the flange, close to the opening edge. In the place where the stresses were measured (Fig. 14), the calculated stress value $(69-70 \mathrm{MPa})$ and the measured one (70 MPa), were similar.

\subsubsection{Study on initial clamp and gasket thickness}

In the case of the gasket of thickness $d=3 \mathrm{~mm}$, the distribution of the contact pressure between the gasket and the flange is almost identical 


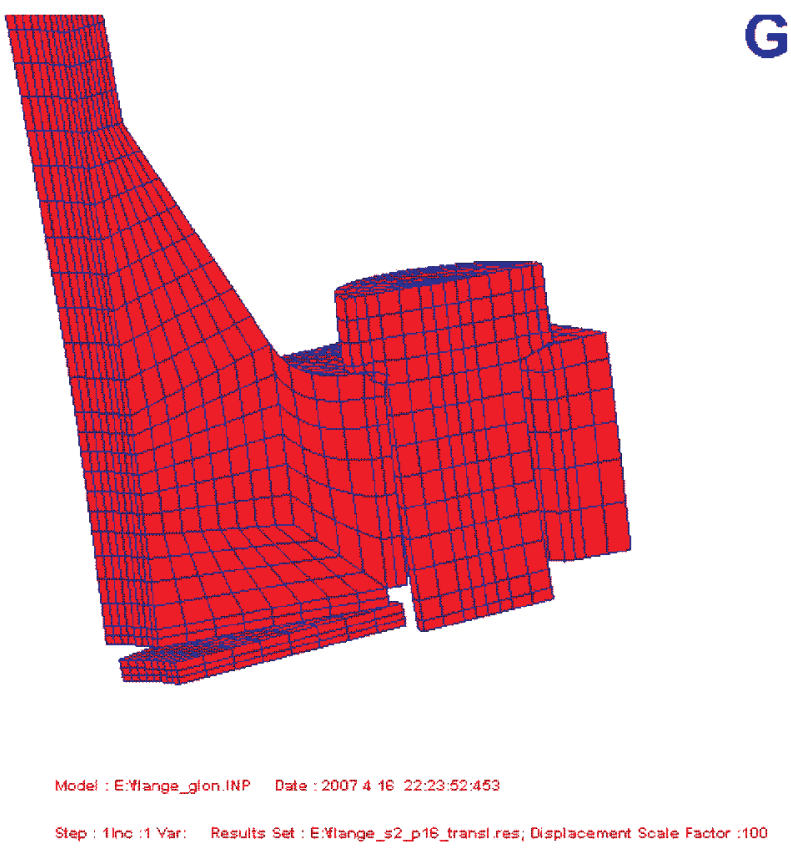

GLON

Fig. 12. Deformed model for applied working pressure of $16 \mathrm{MPa}$

as that in the case of the gasket of thickness $d=5 \mathrm{~mm}$. The values of the contact pressure calculated for the initial clamp of $F=15 \mathrm{kN}$ are presented in Fig. 16.

The change in gasket thickness from $d=5 \mathrm{~mm}$ to the lower value only insignificantly influenced the joint behaviour. Investigating the separation of the gasket and flange we could find that the leakage occurred for the working load of $p=16 \mathrm{MPa}$, irrespective of the gasket thickness. The values of the contact pressure on the gasket of the thickness $d=5 \mathrm{~mm}$, calculated for the initial clamp force of $F=10 \mathrm{kN}$, are presented in Fig. 17 (the results obtained for the force of $F=15 \mathrm{kN}$ are also given for comparison). For the lower initial clamp force, the contact pressure is smaller, in the result of which the leakage occurs for a lower value of the loading due by the working pressure. From the diagram presented in Fig.18, it follows that the leakage takes place for the working pressure slightly exceeding $12 \mathrm{MPa}$. Since for the working load of $14 \mathrm{MPa}$ the contact pressure on the whole gasket surface equals zero, it can be assumed that the value of the working load causing the leakage is $12.5-13 \mathrm{MPa}$.

The change in gasket thickness is practically insignificant for the maximum permissible working load change, on the other hand, the change of the initial clamp force in the bolt has a decisive influence. The greater ini- 


\section{GLON}

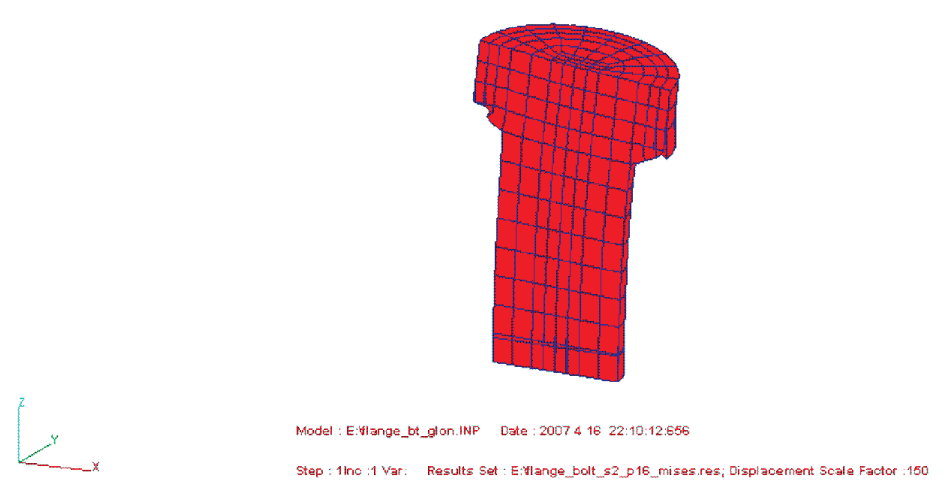

Fig. 13. Bolt in bending

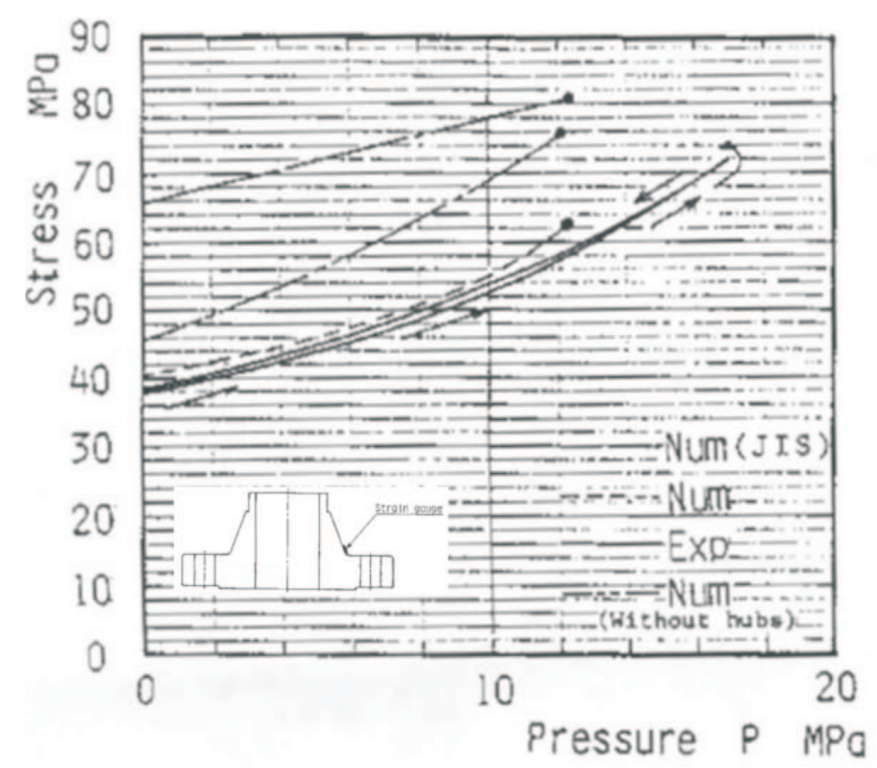

Fig. 14. Tensometric equivalent stresses (measured with strain gauge) in the flange in the function of applied working pressure [12]

tial clamp, the greater maximum permissible loading caused by the initial clamp. The diagram of the maximum contact pressure on the gasket in the function of the bolt clamp force is presented in Fig. 19. Fig. 20 illustrates 


\section{GLON}
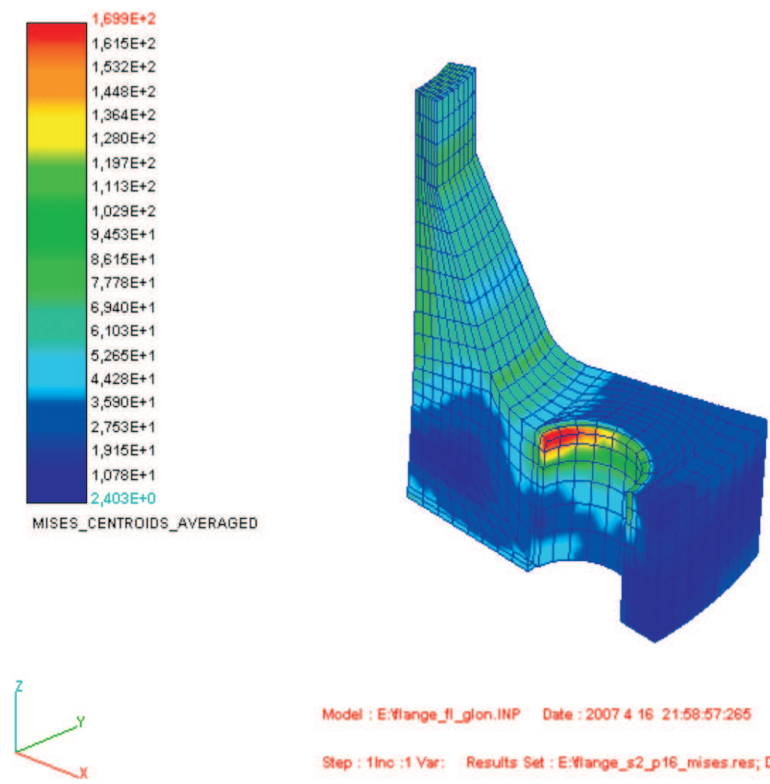

Model : E:tlange fil glon.INP Date : 200741621.58 .57 .265

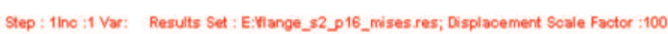

Fig. 15. Distribution of von Mises stresses in flange, MPa

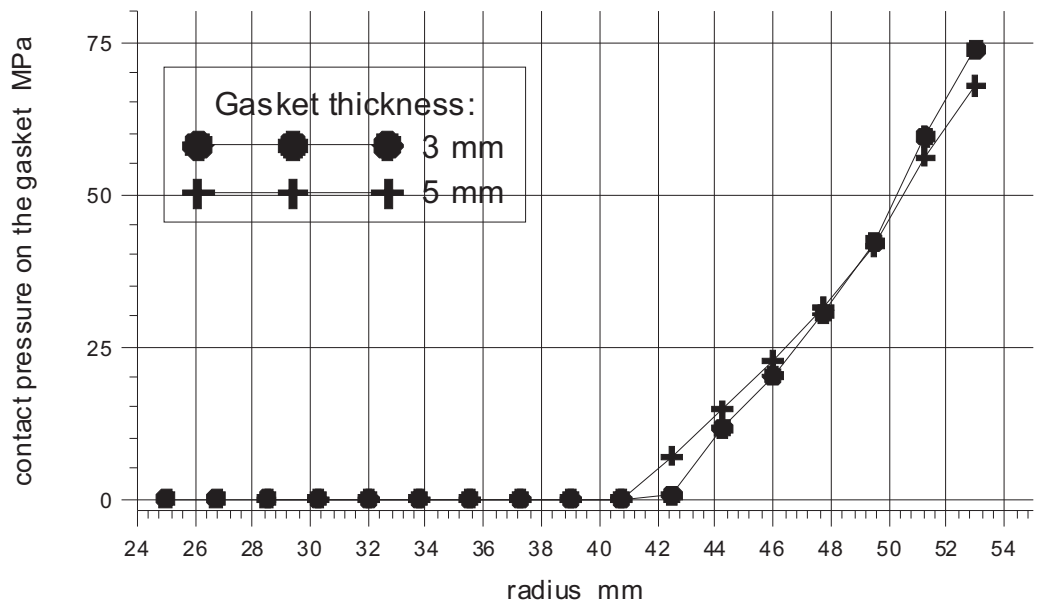

Fig. 16. Value of contact pressure on the gasket $d=3$ and $5 \mathrm{~mm}$ for initial clamp $F=15 \mathrm{kN}$

the relationship between the bolt force and working pressure. We can note that the dependence between the bolt force and the working load changes insignificantly, irrespective of the initial clamp force. 


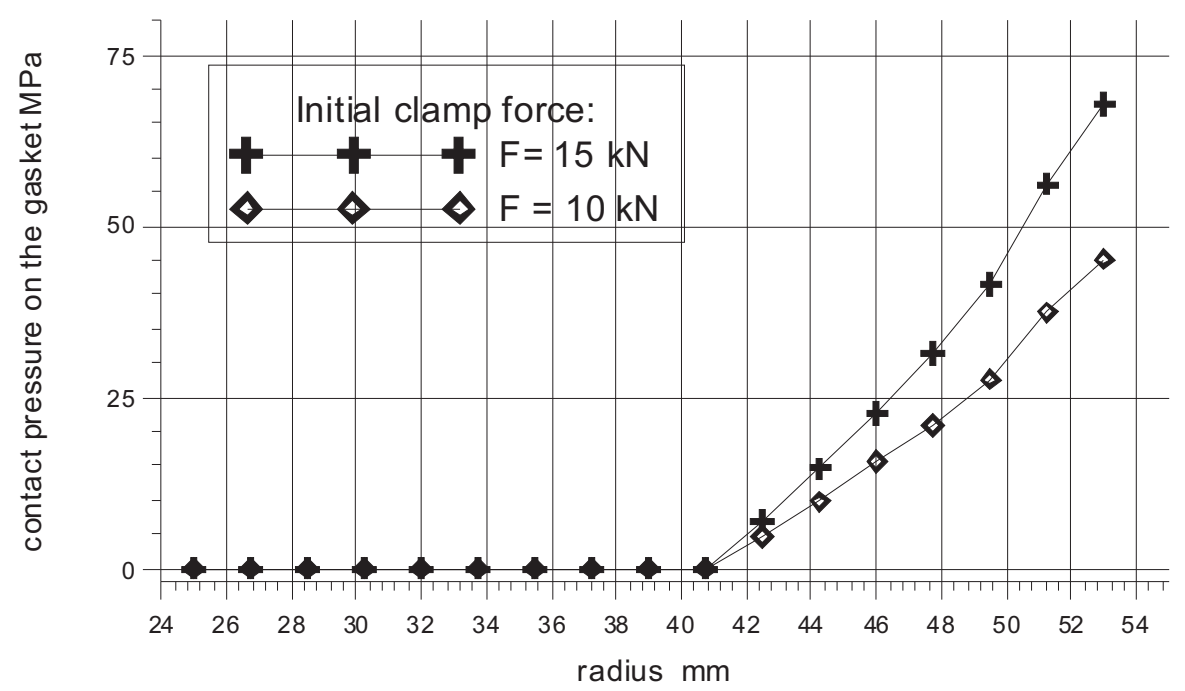

Fig. 17. Contact pressure on gasket $5 \mathrm{~mm}$ (loading by force $F=10 \mathrm{kN}$ )

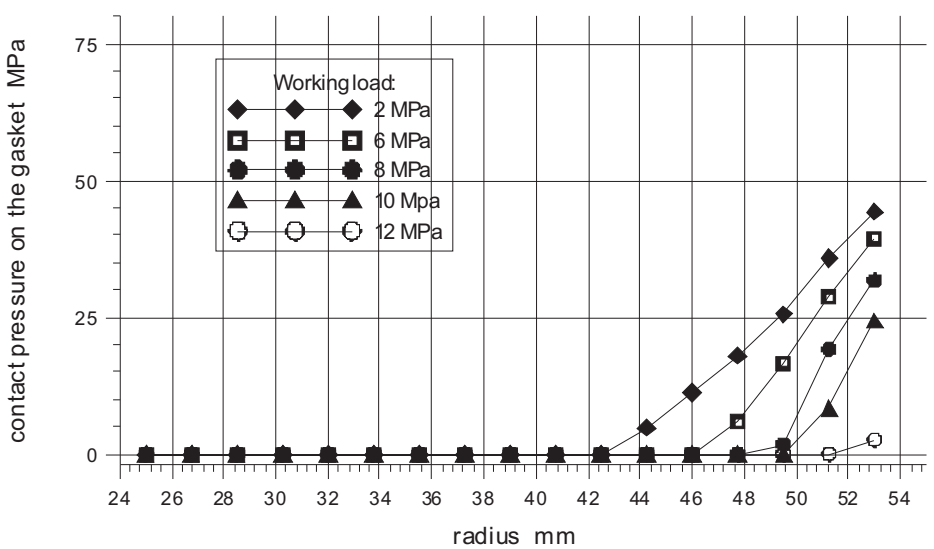

Fig. 18. Contact pressures in dependence on working load for case of initial clamp $F=10 \mathrm{kN}$ (gasket thickness of $5 \mathrm{~mm}$ )

\subsubsection{Stiffness characteristics obtained numerically}

A 3D-model within the finite element method makes it possible to avoid many simplifications assumed in the one-dimensional linear model. Analysing the obtained results we note that the bolt is not only subject to tension and compression but also to bending. Assumptions that the bolt is subject only to tension and compression is thus a considerable simplification. The stiffness characteristics of the bolt and the gasket with the flange, which were obtained numerically with the use of the spatial model, should then be 


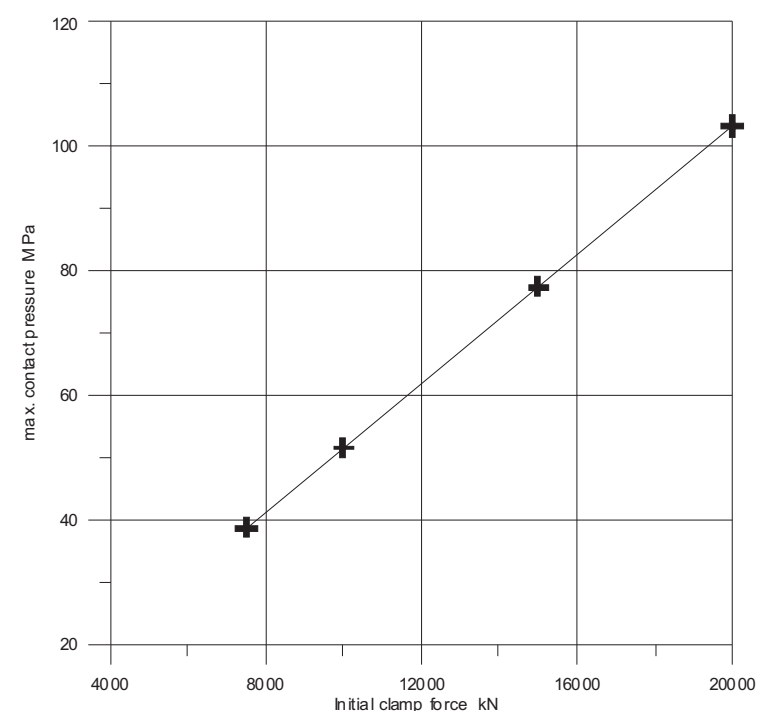

Fig. 19. Maximum contact pressure on gasket in relationship to initial clamp force

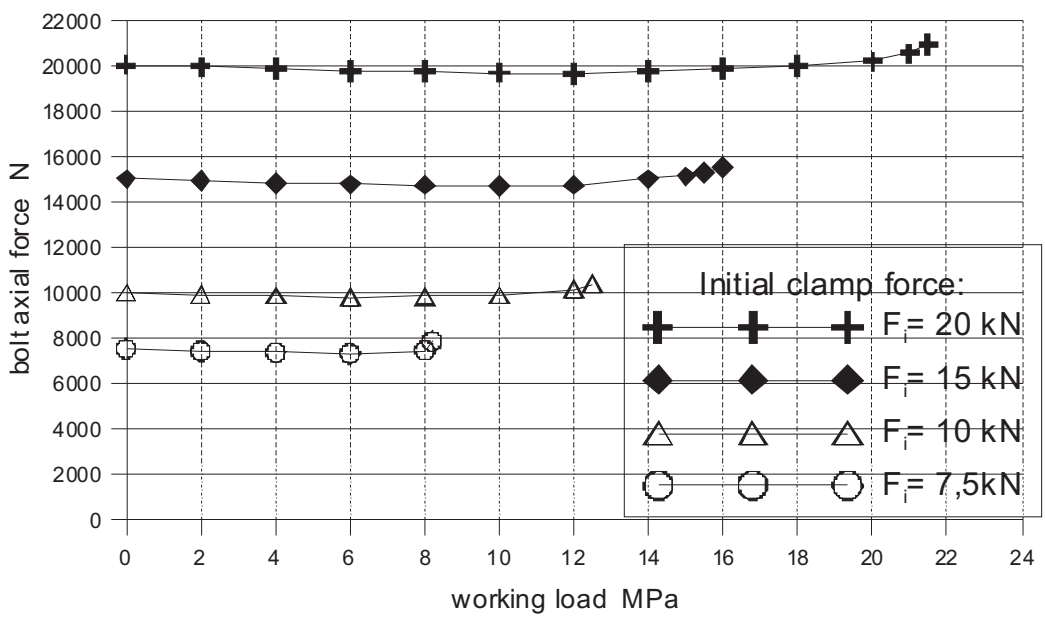

Fig. 20. Bolt force in relationship to working pressure

acknowledged as a good representation of the stiffness characteristics in the real joint.

A deformation-loading diagram, plotted for the obtained stiffness characteristics of the bolt and the gasket, is shown in Fig. 21.

The red line corresponds to the bolt characteristics while the blue one to the gasket characteristics.

As the separation of the flange and the gasket was progressing, the actual working pressure was also applied to the nodes of C3D21 (or C3D28) 
elements belonging to the part of the contact surfaces of the flange bottom only (not the gasket) that were in the separation stage.

Here, the relationships corresponding to the initial clamp from the beginning of the joint loading are nonlinear. It should be noted that the loading due to the working pressure in the gap between the gasket and the flange arising in the effect of progressing separation was additionally considered in the FE model, what had not been taken into account in many recent papers. The green line represents the elongation-loading stiffness characteristics that take into account the influence of the pressure.

The line is considerably divergent from the blue line representing the stiffness characteristics obtained for the case when the influence of the working pressure arising as an effect of progressing opening between the flange and the gasket was neglected.

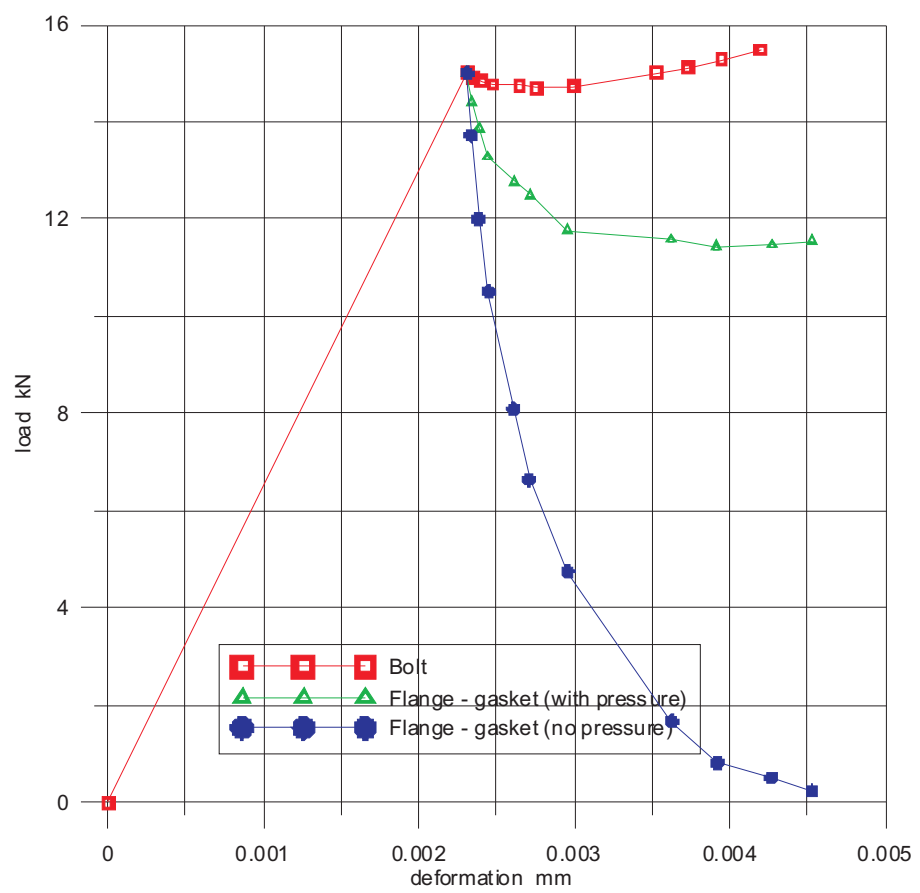

Fig. 21. Deformation-loading diagram for FE 3D-model with (the green characteristic) and without influence of working pressure (the blue characteristic) between the flange and the gasket

\section{Concluding remarks}

Computational results for the initially-clamped bolted joint loaded by working pressure are presented in the paper. The ABAQUS 6.8 finite element 
solver was employed, in which the authors applied both the user's elements, and the developed pre/post-processor software.

Special, spatial 21- and 28-node contact elements were applied to model the contact zone combined with 20-node hexahedral elements for modelling the structure beyond the contact zone. Stiffness characteristics of the joint were developed, considering the influence of the working pressure acting on the bottom surface of the flange while opening between the flange and the gasket was progressing, so that the behaviour of the computational model better represented the real behaviour. A very good agreement between the obtained numerical results and the measurement data given by the other authors was found.

Manuscript received by Editorial Board, May 06, 2010; final version, July 23, 2010.

\section{REFERENCES}

[1] Wiegand H., Kloos K.-H., Thomala W.: Schraubenverbindungen, 5.Auflage, Springer, 2007.

[2] Collins J.A.: Mechanical Design of Machine Elements and Machines, Wiley, 2003.

[3] Krukowski A., Tutaj J.: Połączenia odkształceniowe, PWN, Warszawa, 1987.

[4] Osgood C.C.: Fatigue Design, Wiley, 1970.

[5] Shigley J.E., Mischke C.R.: Mechanical Engineering Design, 5th ed., McGraw-Hill, 1988.

[6] Motosh I.N.: Determination of joint stiffness in bolted connections, J. of Engineering for Industry, Trans. of the ASME, 98, 858-861, 1976.

[7] Junker G.: Systematic computation of highly stressed bolted joints, VDI-Richtlinie 2230, 1972 (in German).

[8] Bickford J.H.: Introduction to the Design and Behavior of Bolted Joints, Marcel Dekker, 1981.

[9] Zahavi E.: A finite element analysis of flange connections', Journal of Pressure Vessel Technology, Trans. of the ASME, 115, 327-330, 1993.

[10] Zahavi E.: The Finite Element Method in Machine Design, Prentice-Hall, 1992.

[11] Zahavi E., Barlam D.: Nonlinear Problems in Machine Design, CRC Press, 2001.

[12] Sawa T., Higurashi N., Akagawa H.: A stress analysis of pipe flange connections', International Journal of Pressure Vessel Technology, Trans. of the ASME, 113, 497-503, 1991.

[13] Buczkowski R.: '21-noded hexahedral isoparametric element for analysis of contact problems', Communications in Numerical Methods in Engineering, 14, 681-692 (1998).

[14] Buczkowski R., Gabbert U.: '28-noded hexahedral isoparametric element for analysis of contact problems', Communications in Numerical Methods in Engineering, 20, 147-161, 2004.

\section{Analiza połączenia kołnierzowego metodą elementów skończonych}

$$
\text { Streszczenie }
$$

W pracy przedstawiono numeryczną analizę połączenia kołnierzowego z uszczelką obciążonego zaciskiem wstępnym i ciśnieniem roboczym. W strefie kontaktu pomiędzy uszczelką a kołnierzem 
zastosowano specjalne przestrzenne 21- i 28-węzłowe izoparametryczne elementy skończone. W modelu obliczeniowym uwzględniono również obciążenie od ciśnienia roboczego panującego w szczelinie pomiędzy uszczelką a kołnierzem w wyniku postępującego otwarcia połączenia, co jest pewną nowością w porównaniu do najnowszych prac opublikowanych z tej tematyki. Sporządzono nieliniowe charakterystyki sztywnościowe śruby i kołnierza z uszczelką. Określono wartość ciśnienia roboczego odpowiadającego sile krytycznej w śrubie powodującego przeciek w połączeniu (całkowicie otwarcie pomiędzy uszczelką a kołnierzem). Wyniki obliczeniowe MES porównano z dostępnymi wynikami doświadczalnymi. Wyniki numeryczne zilustrowano przy pomocy własnego postprocesora graficznego. 